\title{
FLUXOS MIGRATÓRIOS EM TEMPOS DE DEMOCRACIA AGONÍSTICA E A URGÊNCIA POR UMA CIDADANIA DIASPÓRICA
}

\author{
MIGRATORY FLOWS IN TIMES OF AGONISTIC DEMOCRACY AND THE URGE FOR A \\ DIASPORIC CITIZENSHIP
}

\begin{abstract}
Natalia Cintra de Oliveira Tavares
Professora Assistente (Substituta) de Direito internacional da Universidade Federal do Rio de Janeiro. Doutoranda em Direito pela Pontifícia Universidade Católica do Rio de Janeiro. Advogada e Vice-Coordenadora do Centro de Proteção a Refugiados e Imigrantes da Fundação Casa de Rui Barbosa.Contato principal para correspondência.

E-mail: cintratavares@gmail.com
\end{abstract}

\section{Vanessa Oliveira Batista Berner}

Professora Titular na Faculdade Nacional de Direito da Universidade Federal do Rio de Janeiro. Pós-Doutora pela Universidade Federal Fluminense. Doutora em Direito pela Universidade Federal de Minas Gerais. Coordenadora do

Laboratório de Direitos Humanos da UFRJ. Professora convidada do "Centre de DroitInternational" da Université Paris X (UPX), França, para lecionar a disciplina 'DroitInternationaldesMigrations et desRefugiés' no curso Master 2.

E-mail: vanessabberner@gmail.com

Recebido em: 19/12/2018

Aprovado em: 29/04/2019

RESUMO: Partindo da concepção de democracia agonística, proposta por ChantalMouffe, este artigo pretende correlacionar os conceitos de democracia e cidadania, na perspectiva dialética balibariana, a fim de pensar como os fluxos migratórios contemporâneos podem ser pensados não só como movimentos sociais, como entende Sandro Mezzadra, mas também como movimentos insurrecionais, na concepção de Balibar. Partido de tais perspectivas, as migrações poderiam ser pensadas, portanto, enquanto um fenômeno de grande potencial democratizante das sociedades atuais, capazes de tensionar as concepções hodiernas de cidadania e Estado nacional, os quais são incapazes de incorporar as existências migrantes. De natureza metodológica majoritariamente qualitativa e bibliográfica, este trabalho busca pensar um tipo de existência cidadã capaz de questionar as fronteiras internas e externas dos Estados nacionais, e conclui que as migrações invocam um tipo de cidadania que se irá denominar diaspórica, pensada principalmente por Michel Laguerre, um tipo de cidadania transnacional, capaz de movimentar a democracia e transformar as bases nas quais a soberania e o Estado nação se encontram fortalecidos.

Palavras-Chave: Migrações. Democracia Agonística. Cidadania Diaspórica. Diáspora.

ABSTRACT: Starting from the conception of agonistic democracy, proposed by Chantal Mouffe, this article intends to correlate the concepts of democracy and citizenship, in the dialectic Balibarian perspective, so as to think how contemporary migratory flows may be thought of not only as social movements, as understood by Sandro Mezzadra, but also as insurrectional movements, as conceives Balibar. Then, we move forward to conceive migration as a phenomenon of great democratic potential within current societies, capable of tensioning 
contemporary conceptions of both citizenship and Nation State, which are incapable of incorporating migrant existence. Methodologically speaking, this study is mostly of qualitative and bibliographical nature, and seeks to think of a citizen existence able to question internal and external borders of the national States, and concludes that migration evokes a type of citizenship which will be denominated as diasporic, mostly conceived and studied by Michel Laguerre, a sort of transnational citizenship, capable of moving democracy and transforming the bases upon which sovereigntyand the Nation State have solidly built themselves.

Keywords:Migration. Agonistic Democracy. Diasporic Citizenship. Diaspora.

SUMÁRIO: Introdução; 1 Democracia Agonística; 2 Fluxos Migratórios como Movimentos Insurrecionais; 3 Cidadania Diaspórica; Conclusão; Referências Bibliográficas.

\section{INTRODUÇÃO}

Em seu livro Ciudadanía (2013), Etiénne Balibar defende a tese de que cidadania e democracia são noções indissociáveis, ainda que numa relação incessantemente contraditória entre si, denominada pelo autorde momentos dialéticos, os quais são fundamentais para a transformação da política. A cidadania, concebida pelo autor como figura histórica, passa por traduções ao longo dos séculos, reestruturando os modelos de democracia, frente às tensões que lhe são inerentes.

Balibar toma emprestado de Chantal Mouffe o conceito de democracia agonística, para sustentar que o consenso, sem exclusão, é impossível, mesmo dentro do sistema democrático. Para Mouffe (2005), o paradoxo da democracia consiste em que a característica democrática essencial reside exatamente na disputa política, no dissenso, sem o qual a democracia não se sustenta.

É neste sentido que este artigo pretende, em um primeiro momento, explorar o conceito criado por Chantal Mouffe, e seus usos por Balibar, para concluir que ele é a tese mais apropriada para explicar que a dimensão contínua da ideia de democracia é a necessidade do conflito político. No que se refere à cidadania intrínseca a todo modelo de democracia, ela encerra em si uma limitação que lhe é inerente, que Balibar (1998) denomina de princípio do fechamento, isto é, a ideia de que a cidadania não pode ser universal, e que sempre produz, em alguma medida, exclusões. Devemos observar que o conceito moderno de Estado associa o ideal de cidadania nacional à definição clássica de república, levando a que o Estado delimite deliberadamente seu território físico, suas fronteiras e sua jurisdição, a fim de assumir responsabilidades e exercer sua autoridade nacional e internacionalmente. A territorialidade e a nacionalidade são, portanto, elementos essenciais do conceito de cidadaniano mundo moderno, como será explicitado ao longo deste trabalho por meio dos estudos de Juan Carlos Velasco.

Essa limitação, especificamente relevante para a população migrante no mundo, se justifica atualmente na naturalização da correlação entre os conceitos de cidadania e nacionalidade, que revela uma tensão sobre cidadania formal e material, questionando o próprio Estado-Nacional-Social como lugar central de democracia, haja vista a crescente quantidade de cidadãos que não pertencem. Para Balibar, a identificação entre essas duas variáveis se esquece do efeito que produz, que é o efeito da soberania. Para ele, o próprio princípio do fechamento, que produz fronteiras territoriais e humanas, nunca foi questionado devido ao mito da soberania absoluta, construído especialmente na época das invasões imperialistas, mas que entrou em profunda crise após a descolonização do mundo (BALIBAR, 1998, p. 13). A manutenção naturalizada do princípio do fechamento, bem como da identificação entre nacionalidade e 
cidadania, como efeito do Estado soberano, produz exclusões não só externas, mas também internas, compatíveis com um modelo político que institucionaliza o racismo.

Entretanto, referentemente a este ponto, trazemos os apontamentos de Velasco (2009) relativos às experiências migrantes no que tange às mudanças sócio-políticas que tais fluxos produzem, afinal, de acordo com o autor, "as mudanças sociais originadas pelas intensas correntes migratórias se encontram, sem dúvida, entre as mais significativas já registradas durante as últimas décadas" (Velasco, 2009, p. 32, tradução livre ${ }^{1}$ ). É neste ponto em específico que trazemos as discussões propostas por Sandro Mezzadra sobre o direito de fuga, e as conectamos com a ideia de momento insurrecional, de Balibar. Em aula recente, Etiénne Balibar (2017, p. 13) se questiona sobre como resistir à

(...) brutalização da política mundial, como estabelecer uma resistência cívica quanto às instituições e práticas de democracia política, que se encontram, por todo lado, em meio a uma crise profunda e incredibilidade? Uma vez que esse círculo não pode ser dissolvido por meio de uma revelação, uma decisão coletiva repentina, ou pela revolução (ao menos poucos de nós imaginam tal possibilidade), a única coisa a se fazer é explorar projetos e esforços (...). (Tradução livre²).

Um desses projetos é repensar a questão da cidadania naquilo que vem produzindo o apartheid institucional, isto é, recentrar a cidadania não mais na ideia de nacionalidade. De acordo com Balibar (idem, p. 14), é preciso pensar a cidadania

(...)dentro de novos territórios, não em termos de soberania, ou não somente (incluindo soberania popular, membresia no corpo político), mas, ao invés disso, em termos de uma droit de cité, o direito de residir com direitos (também uma possível interpretação da noção de Hannah Arendt (1973) do direito a ter direitos).(grifos nossos) (tradução livre) ${ }^{3}$.

Esse projeto é interessante porque, como defendido pelo próprio Mezzadra, muitos migrantes não ambicionam obter a cidadania (considerando sua concepção identitária, ligada ao nacional) do lugar em que residem, mesmo que estejam ali há muito. Sua situação migrante, que produz um duplo espaço organizado, questiona as ideias então existentes tanto de democracia, quanto de cidadania, e os fundamentos (nacionalidade, soberania) em que estão inseridas.Residir de forma permanente em um território de Estado determinado não implica necessariamente ter nacionalidade ou sequer cidadania. A definição jurídica de nacionalidade deriva da dimensão histórica e de espaço, ocupado pela autoridade estatal. A adoção de critérios de determinação de nacionalidade como iussolis ou ius sanguinis decorre de uma construção definida pela mobilidade da população nacional no mundo ao longo da História. Não houve mudanças significativas nas estratégias de concessão de nacionalidade ao longo do tempo. Ser nacional de um Estado implica a existência de vínculo jurídico com ele, se relaciona com uma categoria de pessoas que detém a soberania a fim de determinar e legitimar o poder instituído, aquele que se manifesta interna e internacionalmente.

\footnotetext{
${ }^{1}$ Traduzido do original, em espanhol: "loscambiossociales originados por las intensas corrientesmigratorias se encuentran, sinduda, entre los de mayor calado registrados durante las últimas décadas".

${ }^{2}$ Traduzido livremente do original, em inglês: (...) Since such a circle cannot become dissolved through a revelation, a sudden collective decision, or a revolution (at least very few among us imagine such a possibility), the only thing to do is to explore projects and efforts (...).

${ }^{3}$ Traduzido livremente do original, em inglês: (...) within new territories not in terms of sovereignty, or not only (including popular sovereignty, membership in the "sovereign" or the "body politic"), but rather in terms of a droit de cité, a right of residing with rights (also a possible interpretation of Arendt's (1973) notion of the right to have rights).
}

Revista de Direito Brasileira | Florianópolis, SC | v. 23 | n. 9 | p.211-227 |Mai./Ago. 2019 
Nacionalidade e cidadania não são conceitos idênticos. O exercício da cidadania está justamente relacionado à democracia, uma vez que implica a possibilidade de seu detentor interferir nas decisões políticas que dizem respeito aos direitos e também a gozar dos benefícios advindos das prestações de serviços por parte do governo. Este cidadão também tem responsabilidades, ficando obrigado a obedecer a lei e pagar taxas, por exemplo. Cidadania é uma condição multifacetada, apresentando-se ao mesmo tempo como um conceito legal, um ideal político de igualdade e uma referência normativa para as ações coletivas. Ela envolve fazer parte de uma comunidade política e participar ativamente dos assuntos públicos. É concomitantemente um status e uma prática política.

O exercício da cidadania se relaciona ao modelo de democracia adotado e aos direitos políticos. Partindo do pressuposto de que se reconhece nas sociedades contemporâneas um traço estrutural que reflete a pluralidade de culturas em seu interior, é de se concluir como fato iniludível que este reconhecimento se aplica a qualquer reflexão significativa sobre a política (VELASCO, 2006).

Nesse sentido, e seguindo a linha de Mezzadra, defendemos a caracterização dos fluxos migratórios contemporâneos enquanto movimentos sociais, dotados de uma potência insurrecional que funciona como o motor da atualidade para a construção de um novo porvir da cidadania, e essenciais para a criação de um novo paradigma democrático, afinal, como menciona Velasco (2009, p. 32, tradução livre), "as migrações podem ser entendidas como o catalizador social, possivelmente o mais decisivo, do conjunto de transformações que está experimentando a instituição da cidadania nas sociedades democráticas contemporâneas"4.

Destaca-se, por fim, que, tendo em vista a natureza do objeto do estudo proposto, aponta-se comosuporte metodológico principal a abordagem qualitativa, especialmente com recurso à base bibliográfica e teórica disponível sobre o tema das migrações, cidadania e democracia, com relevo às suas versões mais críticas, que conseguem lidar com as limitações tradicionais dos conceitos de cidadania e democracia frente à natureza móvel e potentedas migrações.

\section{DEMOCRACIA AGONÍSTICA}

Para muitos estudiosos da democracia, tais como John Rawls e Jurgen Habermas, o consenso é essencial para o processo democrático. Para eles, é possível (e necessário) criar técnicas que alcançam acordos que respeitam tanto a racionalidade normativa, quanto a legitimidade democrática, presente na noção de soberania popular. Ainda que compartilhe da preocupação com as instituições democráticas, na opinião de Chantal Mouffe (2005), a visão consensualista/agregativa é empobrecedora.

Para a autora, a construção dos sujeitos racionais feita pelas teorias consensualistas não considera os afetos e paixões, considerados por ela elementos centrais na concepção dos sujeitos políticos. Dissociados dos afetos, os sujeitos são concebidos como anteriores à constituição das sociedades, portadores de direitos naturais, "abstraídos das relações sociais e de poder" (MOUFFE, 2005, p. 17). Ora, nestes casos, as visões da democracia agregativa não concebem as múltiplas condições de existência dos indivíduos, nem mesmo as condições sociais que os caracterizam, que os dividem, e que produzem hierarquias. Mouffe, reconhecendo essas limitações das teorias habermasiana e rawlsiana, pretende a construção de um indivíduo da democracia por meio da "multiplicação de (...) formas de vida que fomentem a identificação com valores democráticos” (idem, p. 18). Em outras palavras, Mouffe entende que a construção de

\footnotetext{
${ }^{4}$ Do original, em espanhol: "las migraciones pueden ser entendidas como el catalizador social, posiblemente el más decisivo, del conjunto de transformaciones que está experimentando la institución de la ciudadanía en las sociedades democráticas contemporáneas".
} 
uma teoria democrática efetiva deve se basear no pluralismo real, no sentido de fomentar o envolvimento ativo dos cidadãos, e desencorajar formas excessivamente individualistas de viver.

Além disso, outro ponto essencial que distingue Mouffe dos consensualistas reside no fato de que estes postulam que o poder é eliminado da esfera pública, ao passo que para aquela, o poder é constitutivo das relações sociais. Isso significa que as teorias democráticas agregativas, ao desprezar o poder na esfera pública, não conseguem apreender a essência do político ${ }^{5}$, isto é, $o$ antagonismo. Não é possível pensar em uma democracia perfeitamente harmônica, pois o indivíduo da democracia, na concepção de Mouffe, é marcado essencialmente pelo dissenso entre si.

A construção de uma teoria democrática, portanto, não pode prescindir da natureza conflitiva das relações sociais, nem muito menos pretender extingui-las, pois isso aniquila o político; a política se conecta à oposição identitária "nós" e "os outros", sem pretender desfazê-la, pois, para Mouffe, isso é uma impossibilidade, mas constrói a concepção de que "os outros" não são inimigos, mas apenas adversários. O antagonismo social se torna agonismo, situação em que o dissenso é considerado força motriz da democracia, senão veja-se:

(...) Para o "pluralismo agonístico", a tarefa primordial da políticademocráticanão é eliminar as paixões da esfera do público, de modo a tornar possível um consenso racional, mas mobilizar tais paixões em prol de desígniosdemocráticos. Uma das chaves para a tese do pluralismo agonístico é que, longe de pôr em risco a democracia, a confrontaçãoagonística é, de fato, sua condição de existência. (MOUFFE, 2005, p. 21).

O consenso, se existir, é apenas uma condição temporária conquistada por meio da luta agonística, mas nunca uma constante nem um objetivo democrático, vez que é o abandono da ilusão da democracia perfeitamente bem-sucedida, que naturaliza suas próprias fronteiras e exclusões, e essencializa as identidades, que se mantém viva a contestação democrática.

É com base nessa concepção que Balibar desenvolve sua tese da relação intrínseca, porém antinômica e contínua entre democracia e cidadania. $\mathrm{O}$ autor compreende a cidadania como um conceito historicamente determinado pelas condições sociais, políticas e culturais determinados em tempo e espaço, e em constante disputa, a depender das tensões próprias do momento democrático vivido. Para o autor,

(...) Esta inscrição da cidadania no horizonte da comunidade não é de algum modo sinônimo de consenso ou homogeneidade, senão todo o contrário, posto que os direitos que ela garante fora conquistados, é dizer, foram impostos apesar da resistência oposta por aqueles que detêm privilégios, interesses particulares e poderes que expressam tantas dominações sociais. (BALIBAR, 2013, p. 62, grifos nossos, tradução livre) ${ }^{6}$.

Ao construir seus argumentos, Balibar retorna às origens da democracia, analisando o conceito - e as contradições - presentes na politéia grega, nas revoluções burguesas do século XIX, nas contradições da "Cidadania Social”, até pensar se é possível falar em democracia nas

\footnotetext{
${ }^{5}$ Mouffe (2005, p. 20) distingue os termos "o político" e "politica". Para ela, "o político" se refere ao antagonismo inerente às relações humanas. "Política", por outro lado, se refere aos mecanismos criados para construir a coexistência humana, que será sempre conflitiva, devido às condições de influência "do político".

${ }^{6}$ Traduzido do original, em espanhol: “(...) Esta inscripción de la ciudadanía en el horizonte de la comunidad no es de ningún modo sinónimo de consenso o de homogeneidad, sino todo lo contrario, puesto que los derechos que esta garantiza han sido conquistados, es decir que han sido impuestos a pesar de la resistencia opuesta por quienes detentan privilegios, intereses particulares y poderes que expresan tantas dominaciones sociales".
} 
respostas neoliberais ao Estado-Nacional-Social em crise. Sua tese sustenta que, após séculos de transformações do modelo democrático, o essencial para a defesa das instituições democráticas é, ao fim e ao cabo, o caráter inevitável da dialética, e os impulsos democratizantes por elas promovidos, que são recursos para o exercício da cidadania.

Ressalta-se que democracia, para Balibar, não corresponde à configuração formal, estatal, da política, e.g. com o advento de uma constituição formal, mas é constituída por meio de processos de democratização, ou, em outras palavras, na reivindicação ativa da democracia. Da mesma maneira, cidadania não corresponde ao conceito formal, hodiernamente confundido com sua esfera nacional, construída para traduzir a linguagem soberana do Estado, e subordiná-la ao seu funcionamento, colocando os cidadãos apenas como uma função estatal, uma comunidade passiva: a cidadania é um conceito ativo para Balibar, capaz de pressionar as instituições democráticas influenciadas pela esfera do político, pois ele vê a cidadania

(...) não como uma noção fixa, com uma essência permanente que seria simplesmente adaptada a sucessivos quadros políticos, mas como um problema permanentemente em aberto, que já esteve sujeito a mutações, colapsos e redefinições na história. (BALIBAR, 2017, p. 04, grifos nossos, tradução livre) ${ }^{7}$.

Sendo um problema permanentemente em aberto e em disputa, "a cidadania não somente deve ser atravessada por crises e tensões periódicas, ela é intrinsicamente frágil ou vulnerável"pois experimenta crises levadas a cabo pela própria potência constituinte, isto é, “a capacidade insurrecional dos movimentos políticos (...) que buscam conquistar direitos ainda inexistentes, ou ampliar os existentes, de modo a fazer com que a igualdade-liberdade se concretize na prática”(BALIBAR, 2013, p. 63, grifos nossos, tradução livre) ${ }^{8}$.

Os momentos insurrecionais, levados à cabo pelos movimentos sociais, contribuem, portanto, com o desmantelamento das instituições e a construção de um novo modelo de sociedade e de cidadania subjacente. Cabe pensar se essa noção levantada por Balibar se aproxima dos teóricos críticos dos direitos humanos que entendem que estes são o resultado das lutas sociais, ou, nas palavras balibarianas, movimentos insurrecionais. Tanto Helio Gallardo (2009), quanto Herrera Flores (2002), sustentam que as lutas sociais são essenciais para a constituição dos direitos humanos. Ainda que não falem propriamente de cidadania ou democracia, ambos os autores indicam a potência transformadora dos movimentos sociais na constituição de direitos e transformação do status quo, inserindoa discussão dentro do paradigma dos direitos humanos.

De qualquer maneira, a intenção de Balibar é clara no sentido de que a democracia não é dada, mas sim um processo de construção social que nasce de luta e dissensos entre os membros de uma mesma sociedade. No entanto, falar de uma "mesma sociedade" implica compreender que há pessoas que não podem compô-la, ainda que ali vivam, ou que queiram ali viver. Ora, ainda que a identificação moderna dos conceitos de nacionalidade e cidadania tenham enfraquecido, há resquícios fortes que se materializam em exclusões normativas, econômicas, políticas e simbólicas. As fronteiras externas, portanto, constituem os participantes formais de uma comunidade, ainda que dentro dela existam muitas outras fronteiras, afinal, as exclusões não são só formais.

\footnotetext{
${ }^{7}$ Traduzido do original, eminglês: “(...) not as a fixed notion, with a permanent essence that would become simply adapted to successive political cadres, but as a permanently open problem, which has already been subjected historically to mutations, collapses, and redefinition".

${ }^{8}$ Traduzido do original, em espanhol: "la ciudadanía no sólo debe ser atravesada por crisis y tensiones periódicas, sino que es intrínsecamente frágil o vulnerable (...). (...) La capacidad insurreccional de los movimientos políticos (...) que buscan conquistar derechos todavía inexistentes, o ampliar los existentes, de modo de hacer que la iguallibertad pase a los hechos".
}

Revista de Direito Brasileira | Florianópolis, SC | v. 23 | n. 9 | p. 211-227 |Mai./Ago. 2019 
Neste sentido, Balibar sustenta que a profundidade da exclusão deve ser medida na potência de atuação, de resistência à condição de excluído. Ele recupera a noção arendtiana do "direito a ter direitos", que se refere à "capacidade ativa de reivindicar direitos no espaço público, ou, melhor ainda, dialeticamente, da possibilidade de não ser excluído do direito a lutar pelos seus direitos"'(BALIBAR, 2013, p. 109, tradução livre) ${ }^{9}$. Assim sendo, haveria um limite entre a possibilidade de resistir (e de existir politicamente), que seria o direito mínimo, e o nãodireito, que é mais propriamente a exclusão, como é o caso de agrupamento de migrantes, campo de refugiados, etc., ainda que eles estejam em comunidades democráticas. Balibar fala que a resistência nem sempre é possível - sendo imprescindível, nesses casos, a violência antiinstitucional, a fim de forçar o ingresso ao espaço da cidadania.

No entanto, a constituição atual de democracia e cidadania não é nada mais do que apenas uma das formas assumidas pela comunidade de cidadãos - é, portanto, uma estrutura em disputa, sujeita aos momentos insurrecionais e às transformações deles decorrentes.

O mundo contemporâneo se caracteriza por ser globalizado, multicultural e transnacional. Nessa perspectiva, questiona-se a manutenção de uma política fechada para o estrangeiro. A primazia de valores como unidade de cultura e de nação pode - e deve - ser problematizada, uma vez que se evidencia como demonstração restritiva de direitos, pois concebe um modelo identitário imposto aos indivíduos que pertencem a uma determinada comunidade. Ademais, se propõe a relativização do próprio termo unidade cultural integral, uma vez que grupos sociais e nações seriam constituídos a partir de múltiplas fontes culturais. Conforme destaca Benhabib, "em si mesmas, nem as culturas nem as sociedades são holísticas, mas são sistemas de ação e significação poli-vocais, descentralizados e fraturados, que abarcam vários níveis" (2006, p. 61).Ao contrário, uma nação teria muito a ganhar com o intercâmbio de culturas e conhecimentos que se podem firmar. Nas palavras de Charles Taylor:

Nos transformamos em agentes humanos plenos, capazes de nos compreender a nós mesmos e, portanto, de definir nossa identidade por meio de nossa aquisição de linguagens humanas enriquecedoras para nos expressarmos. (TAYLOR, 1993, p. 52).

José Luis Giovanoni Fornos (2008, p. 02) vai além: “os imigrantes devem ser tomados como personagens centrais na configuração das chamadas geografias nacionais, enriquecendo o debate acerca da categoria nação, problematizando a historiografia literária". E como enfatiza Edward Said, "a moderna cultura ocidental é, em larga medida, obra de exilados, emigrantes, refugiados" (SAID, 2003, p. 46).Em verdade, concordamos com SeylaBenhabib ao ponderar que:

Hoje em dia, a maioria de nós pertence a mais de uma comunidade, um grupo lingüístico, um ethos. Milhões de pessoas em todo o mundo realizam migrações econômicas, políticas ou artísticas. Mais que nunca, as 'nações verdadeiras', os grupos lingüísticos 'puros' e as identidades étnicas não contaminadas são em verdade comunidades 'imaginadas'. Estas foram criadas pela imaginação dos poetas (...) (BENHABIB, 2006, p. 72).

No mesmo sentido pontua Stuart Hall:

A identidade é irrevogavelmente uma questão histórica. Nossas sociedades são compostas não de um, mas de muitos povos. Suas origens não são únicas, mas diversas. Aqueles aos quais originalmente a terra pertencia, em geral, pereceram

\footnotetext{
${ }^{9}$ Traduzido do original, em espanhol: "capacidad activa de reivindicar derechos en un espacio público, o, mejor
} aún, dialécticamente, de la posibilidad de no ser excluido del derecho a luchar por sus derechos".

Revista de Direito Brasileira | Florianópolis, SC | v. 23 | n. 9 | p.211-227 |Mai./Ago. 2019 
há muito tempo. Todos que estão aqui pertenciam originalmente a outro lugar. (HALL, 2003, p. 30).

Considerando-se que não há "grupos puros", soam incongruentes as teorias que sugerem uma separação rígida entre os povos. As diferenças culturais não deveriam ser utilizadas como instrumento de negação da igualdade humana, se formos analisar a partir da perspectiva dos direitos universais. Neste sentido, Seyla Benhabib ressalta que "o diálogo e a coexistência cultural são reais, inevitáveis e necessários" (BENHABIB, 2006, p. 93). Assim, ainda que haja uma defrontação mais dura por parte dos Estados, não há possibilidade de se inibir o ritmo dos fluxos migratórios e, consequentemente, dos intercâmbios culturais. Uma estratégia mais eficiente, do ângulo da satisfação plena do ser humano, seria permitir o livre fluxo e circulação de pessoas. Neste sentido, a troca entre culturas deveria ser vista como positiva, e não abordada no intuito de se anular as diferenças que constituem a identidade dos indivíduos. Conviver dialogicamente com outras identidades não implicaria homogeneização.

É nesse sentido, pois, que pretendemos explorar o potencial insurrecional dos movimentos humanos no mundo contemporâneo, bem como a potência da fuga como instrumento democratizante, por entender que os fluxos migratórios são hoje uma das expressões de rechaço mais manifestas que há, isto é, os migrantes demonstram na materialidade de seus corpos e vidas (ou mortes) a urgência de reconsiderar os fundamentos das democracias atuais. Para isso, fazemos uso da construção de Sandro Mezzadra de direito de fuga, tão necessária como ferramenta analítica do caráter do político, antagônico, que representam as migrações.

\section{FLUXOS MIGRATÓRIOS COMO MOVIMENTOS INSURRECIONAIS}

Mezzadra, diferentemente da maioria dos estudiosos das migrações, objetiva ressaltar o caráter subjetivo das migrações, ao invés de suas causas objetivas, isto é, os fatores geopolíticos, ambientais, entre outros, que motivaram o deslocamento. Ao concentrar-se na fuga, o autor enfoca "sua natureza específica de movimento social" (MEZZADRA, 2005, p. 45, tradução livre $)^{11}$, distanciando-se, portanto, da concepção de que é um evento natural, direta e unicamente explicado por causas objetivas. Mezzadra enfatiza que essa visão foi bastante influenciada pelas leituras feministas dos fenômenos migratórios, em especial das mulheres migrantes, que se deslocam não somente devido às condições econômicas e/ou ambientais que lhe precedem, mas também, e em alguns casos, principalmente, porque buscam sociedades em que as relações patriarcais lhes são menos nocivas ${ }^{12}$.

\footnotetext{
${ }^{10}$ Mezzadra, ao construir o caráter de movimento social subjacente às migrações se volta aos estudos weberianos acerca dos migrantes que abandonam o trabalho rural para ir às cidades para indicar que a mobilidade espacial representou a gênese, na Alemanha, da luta de classes, vez que o trabalhador migrante não só vivia de interesse econômico, mas de ilusões (Max Weber apud MEZZADRA, 2005, p. 62) que são, por sua vez, materialmente operativas, no sentido de serem capazes de ativar a insurreição contra os proprietários de terra e as condições laborais. De fato, o migrante encarna em sua pele os efeitos mais duros de viver com a liberdade de movimentar-se, seja pela razão que for; a movimentação espacial tem no migrante seu expoente principal, e configura a luta contra as figuras que impedem sua expressão e, em última instância, contra o capitalismo.

${ }^{11}$ Traduzido do original, em espanhol: "su naturaleza especifica de movimiento social".

${ }^{12}$ Não pretendo, com essa exposição, dizer que as sociedades de destino são matriarcais, ou mais culturalmente evoluídas que aquelas de saída; pelo contrário, destaco que, no geral, a cultura europeia imposta ao restante do mundo resultou na implantação forçada do patriarcado, que hoje se expressa de maneiras por vezes nocivas a mulheres, resultando, pois, na fuga, não para uma sociedade "melhor", mas uma que ofereça soluções às necessidades imediatas que tenham as mulheres migrantes. Como exemplo, mulheres iranianas ou sauditas que querem ampliar sua existência civil e política, ou mulheres somalis que não queiram ser sujeitas a práticas de mutilação genital feminina.
} 
A consequência de uma análise das motivações subjetivas das migrações é revestir os migrantes, individual e coletivamente, de existência política, é reconhecer a condição materialmente ontológica de resistência do fenômeno da fuga, é a não reprodução das leituras paternalistas que envolvem o fenômeno migratório, "que relegam aos migrantes uma posição subalterna, negando-lhes toda oportunidade de subjetivação"(idem, p. 46, tradução livre) ${ }^{1314}$.

De acordo com Mezzadra, portanto, os fluxos migratórios, em geral, demonstrama outra globalização, ou a globalização "desde abaixo" (ibidem, p. 49, tradução livre) $)^{15}$, este movimento global que sinaliza as consequências violentas da globalização capitalista. Ora, se consideramos que o porvir da cidadania é construído nas invenções democráticas que vêm desde abaixo, será que não é possível pensar que os fluxos migratórios, considerados em sua perspectiva subjetiva, a da fuga, representam um movimento global que pressiona as estruturas capitalistas da globalização moderna e, por consequência, das estruturas de democracia e de cidadania que a sustentam? De fato, como ensina Velasco,

Essa configuração dos processos migratórios, mediante redes transnacionais faz visível uma face da globalização diferente daquela mais habitual: uma globalização em que as implicações 'macro', sistêmicas ou estruturais do processo (uma globalização desde acima) não têm tanto protagonismo, mas sim aquelas que se inserem no nível 'micro' dos processos sociais (uma globalização desde abaixo), mais próxima do mundo da vida.

. (VELASCO, 2009, p. 35, tradução livre) ${ }^{16}$

Ainda que, de acordo com Balibar (2013), toda prática política esteja territorializada, a condição migrante de desterritorialização e reterritorialização constante tensionam a ideia de cidadania atual, levando ao questionamento se não seriam os migrantes os cidadãos porvir (idem, p. 135). Nesse sentido, é imprescindível que as questões dos direitos à residência e à circulação, essencialmente cosmopolitas, saiam da esfera única dos direitos humanos e passem a fazer parte essencial da cidadania política, sob o risco da manutenção da ideia de soberania estatal e sua função policial de controle de fronteiras, deixando aos organismos internacionais e às ONGs a responsabilidade de dar conta da administração da crescente massa de não cidadãos "nem daqui nem de outro lugar"(ibidem, p. 136, tradução livre) ${ }^{17}$, reduzida à esfera humanitária. A fuga representa, portanto, material e simbolicamente, a resistência a esse modelo excludente e nocivo de cidadanianacional e de soberania.

A cidadania, concebida apenas no seu sentido formal, olvida o seu caráter subjetivo, isto é, de movimento e ação. Nesse sentido, a fuga, elemento desterritorializante e, ao mesmo tempo, reterritorializante, consiste em manifestações do político tanto nos locais de onde saíram os fluxos, quanto naqueles a que chegaram. São espaços diaspóricos, em que se multiplicam figuras híbridas, que existem para além da dicotomia nacionais e estrangeiros; são responsáveis, por essa

\footnotetext{
${ }^{13}$ Também, conforme ensina Mezzadra (2005, p. 84), “(...) desde el punto de vista historiográfico establece una especie de automatismo en el origen de los movimientos migratorios, con el riesgo de desplazar una vez más del escenario a los «individuos sin historia» de cuyos movimientos son protagonistas".

${ }^{14}$ Traduzido do original, em espanhol: "que relegan a los migrantes a una posición subalterna, negándoles toda oportunidad (chance) de subjetivación”.

${ }^{15}$ Do original, em espanhol "desde abajo".

${ }^{16}$ Do original, em espanhol: "Esta configuración de los procesos migratorios mediante redes transnacionales hace visible una cara de la globalización diferente a la más habitual: una globalización en la que toman protagonismo no tanto las implicaciones 'macro', sistémicas o estructurales del proceso (una globalización desde arriba), sino aquellas que se insertan en el nivel 'micro' de los procesos sociales (una globalización desde abajo), más cercano al mundo de la vida".

${ }^{17}$ Do original, em espanhol, "ni de aquí ni de otro lugar".
}

Revista de Direito Brasileira | Florianópolis, SC | v. 23 | n. 9 | p.211-227 |Mai./Ago. 2019 
razão, pela tensão e pelo desmoronamento do paradigma da nacionalidade e soberania tradicionais.

Nesse sentido, a vivência dos migrantes, enquanto cidadãos da fronteira, é de um duplo espaço político e cultural, que confere à situação migrante a caracterização de diaspórica, no sentido de implicar uma diferenciação "tanto da pátria mãe, quanto da nação de residência" (MEZZADRA, 2005, p. 103). Subjaz ao conceito de diáspora, portanto, a ideia da suspensão de identidade, ou, dito de outra maneira, o atravessamento contínuo de fronteiras e de identidades, "alimentando lutas por cidadania e por liberdade" (Paul Gilroyapud MEZZADRA, 2005, p. 104). Ora, o migrante, como um cidadão de fronteiras, por elas constituído conceitual e praticamente, também se encontra em um duplo espaço político, oscilando entre as distintas identidades que o constitui e corporificando as lutas por direitos, em especial o direito à mobilidade e à residência.

O problema de serem constituídos enquanto diaspóricos, ou cidadãos de fronteiras, não diz respeito à suposta necessidade, ou desejo, de obter a nacionalidade do local de destino para que tenham acesso ao espaço da cidadania formal. Na realidade, "os migrantes raramente buscam uma adesão incondicionada ao país e à cultura de assentamento, alimentando uma aspiração à naturalização"(idem, p. 104, tradução livre) $)^{18}$, ao mesmo tempo que "entre os direitos das minorias está também o de renunciar sua cultura"(ibidem, p. 114, tradução livre) ${ }^{19}$. Assim sendo, os migrantes problematizam as respostas jurídico-políticas existentes no interior da sociedade nacional; não sustentam o mito do desejo de retorno, nem mesmo aquele de que querem se inserir a uma outra comunidade de nacionais. Eles tensionam, de fato, o direito de permanecer, ou de residir, enquanto essenciais à entrada na comunidade política, não de maneira formal, isto é, como um status legal, mas como uma forma de identidade política dentro das sociedades de destino (MEZZADRA, 2005, p. 118). De fato, como já mencionou Castles (apud VELASCO, 2009, p. 34, tradução livre), "os esforços estatais de controlar a migração seguem ainda uma lógica nacional, ao passo que muitas das forças que determinam a migração seguem a lógica transnacional" ${ }^{20} \mathrm{ou}$, no caso a lógica diaspórica.

O recentramento do conceito de cidadania, pois, é constantemente tensionado pelos movimentos migratórios, devido ao seu caráter insurrecional de movimento social. Não se trata, portanto, de uma demanda por se tornar cidadãos franceses, canadenses, estadunidenses ou mesmo brasileiros,

(...) mas que eles obtenham uma quantidade crescente de direitos cívicos igualitários em uma determinada circunscrição. Nesse sentido, eles se tornariam "co-cidadãos" (em semelhança à expressão "compatriotas"), que, por um lado, simplesmente remonta às origens da noção, vez que no latim, civis é uma noção relacional, não significa a unidade dos cidadãos, mas sim a relação entre tais co-cidadãos, aqueles que são "iguais" ou "igualmente desfrutam" dos direitos ou liberdades da cidade.. (BALIBAR, 2017, p. 14, grifos nossos, tradução livre $)^{21}$.

A noção diaspórica de cidadania prescinde do vínculo de nacionalidade entre os indivíduos e entre estes e o Estado exatamente porque encontra, nas comunidades migrantes e

\footnotetext{
${ }^{18}$ Do original, em espanhol: "los migrantes raramente se vuelcan en una adhesión incondicionada hacia el país y la cultura de asentamiento, alimentando una aspiración a la naturalización”.

${ }^{19}$ Do original, em espanhol: "entre los derechos de las minorías está también el de renunciar a su cultura”.

${ }^{20}$ Do original, em espanhol: "los esfuerzos estatales por controlar la migración siguen todavía una lógica nacional, mientras que muchas de las fuerzas que determinan la migración siguen la lógica transnacional”.

${ }^{21}$ Do original, em inglês: "(...) but that they acquire an increasing amount of equal civic right within a given constituency. In that sense they would become rather "co-citizens" (formed after the expression: "compatriots"), which in a sense simply returns to the origins of the notion, since in Latin civis is a relational notion, it does not mean the unity of the citizens, but before that the relationship between the co-citizens, those who are "equals," or "equally enjoy" the rights or freedoms of the city".
}

Revista de Direito Brasileira | Florianópolis, SC | v. 23 | n. 9 | p. 211-227 |Mai./Ago. 2019 
diaspóricas, um duplo espaço político. A sua relação com a comunidade política de destino é, essencialmente, a de compartilhar, pelo vínculo da residência, o espaço geopolítico. É neste sentido que, a noção diaspórica de cidadania tem como seu fundamento o direito de residir com direitos, o direito à cidade, numa livre interpretação da concepção arendtiana do direito a ter direitos (BALIBAR, 2017).

Essa reivindicação, por sua vez, é capaz de ruir as bases nacionalistas nas quais a cidadania foi constituída, e de onde produz tantas tensões no interior das sociedades modernas. Os movimentos sociais migratórios, por meio da sua simples existência nas comunidades políticas atuais, pressionamo significado do pertencimento com base na cultura, e propõem uma lente distinta, com base no direito a residir, e na convivência política entre os residentes de um mesmo espaço geopolítico.

Se pensarmos no exercício da cidadania material e fática, mesmo os migrantes irregulares, sem qualquer direito formal, são responsáveis pelo tensionamento das condições modernas de acesso a direitos, exatamente porque têm uma experiência política, econômica, cultural, simbólica e corporal de exclusão. O fato de estarem constantemente sujeitos à deportação e à detenção administrativa, corporifica no migrante (em especial o irregular, mas não só nele) a experiência de exclusão da sociedade política. Sua (r)existência é vivida continuamente enquanto cidadão de fronteiras, essencial para a construção de um novo porvir cidadão, especialmente quando consideramos que

(...) cada configuração identitária (começando como já foi dito, pela nacional) parece investida de múltiplas tensões, circunstância que favorece a difusão de tendências de reações defensivas e reativas em 'pequenas pátrias' mais ou menos abertamente racistas (MEZZADRA, 2005, p. 99, tradução livre) $)^{22}$.

O momento insurrecional inaugurado pelos migrantes é, ao fim e ao cabo, uma disputa de sentidos no âmbito do político, frente à institucionalização generalizada do racismo ${ }^{23}$, do conceito de cidadania. Há atualmente uma tensão entre o novo significado de igualdade democrática, apenas baseada no conceito de republicanismo, posto que a essência do republicanismo é justamente a capacidade do cidadão fazer a lei ${ }^{24}$. Entretanto, sendo distintos o estatuto de nacional e o estatuto de cidadão, e por haver limites jurídicos para que se possa adquirir a cidadania, a igualdade que gozam os estrangeiros é limitada, pois pouco influenciam na construção da norma que os atinge, ainda que haja à disposição modernos mecanismos para participar da vida política nos ordenamentos estatais. Ao mesmo tempo, há uma potência insurrecional que é perceptível tanto no interior das comunidades políticas, nas vivências e demandas de migrantes regularesou não, mas também em seu exterior, corporificada na vida e morte de migrantes que reivindicaram seu direito de fuga.

\footnotetext{
${ }^{22}$ Do original, em espanhol: “(...) cada configuración identitaria (comenzando, como se ha dicho, por la nacional) parece investida de múltiples tensiones, circunstancia que favorece la difusión de tendencias de repliegue defensivo y reactivo en «pequeñas patrias» más o menos abiertamente racistas".

${ }^{23}$ Balibar afirma que "racism, which is never a purely "psychosociological" phenomenon, but always has a decisive institutional dimension (...) is encouraged by the fact that the State targets and stigmatizes immigrants, but also by the fact that, apparently, it does not want to really close the borders. In Foucauldian terms, it rather displays itself as a bio-political management of illegality" (Balibar, 2017, p. 05). Ao criar status de ilegalidade humana, ao fechar as fronteiras, mas ainda permitir a entrada de migrantes, o Estado Nacional-Social manifesta suas intenções soberanas de controle e administração biopolítica da ilegalidade, demonstrando uma face sombria da institucionalização do racismo. As migrações, enquanto movimento social, buscam, por meio da fuga, combater esse aspecto estruturalmente racista da globalização capitalista.
}

${ }^{24}$ Há concepções distintas de cidadania entre o liberalismo e o republicanismo. Na concepção republicana cidadania tem a ver com a participação na esfera pública e é neste sentido que a compreendemos neste artigo. Ver VELASCO, J. La noción republicana de ciudadanía y la diversidade cultural. Isegoría, v. 33, 2006, pp 191-206.

Revista de Direito Brasileira | Florianópolis, SC | v. 23 | n. 9 | p.211-227 |Mai./Ago. 2019 


\section{CIDADANIA DIASPÓRICA}

O movimento, ou a fuga, responsável, como mencionamos, pela construção de um porvir cidadão, inscreve esses sujeitos em entre-lugares. Se, ainda na introdução, refutamos a ideia de um conceito de cidadania tradicional, formal, uma vez que produtor de "cidadãos" que não pertencem, entendemos que a experiência migrante é motivadora de novas existências cidadãs, responsáveis por impulsos e desígnios democráticos motivadores de novos modelamentos da democracia. Conforme já disse Velasco (2009, p. 36, tradução livre), "vinculadas aos processos de globalização e ao progressivo reconhecimento dos direitos humanos, estão surgindo pela via fática novos modelos de cidadania, com um componente territorial e nacional muito menos marcado" 25 .

Nesse sentido, concebemos que os migrantes não são cidadãos que não pertencem, haja vista pertencerem a mais de um lugar. Essa característica de transnacionalismo, esse duplo lugar essencial do migrante, "tem a virtude de iluminar as contradições internas do projeto moderno de cidadania nacional" (VELASCO, 2009, p. 32, tradução livre) ${ }^{26}$, e o inscreve na ordem da cidadania diaspórica, conceito este brevemente mencionado no tópico anterior. Definição construída pelo norte-americano Michel Laguerre, ao analisar a experiência transnacional cidadã das comunidades haitianas nos Estados Unidos da América (EUA), com enfoque na experiência mais contemporânea. Para o autor, diáspora e cidadania são, na sua essência, antagônicas, haja vista que esta teria um sentido que invoca ao sedentarismo, ao passo que aquela denotaria o nomadismo, a mobilidade. Assim que, apesar de aparentemente paradoxal, o termo cidadania diaspórica seria necessário não só para compreender as experiências da vivência migrante, mas para reposicionar as bases nas quais se coloca a noção de cidadania e, portanto, de democracia.

Assim, por um lado, diáspora significa deslocamento da pátria-mãe ao mesmo tempo que implica um re-enraizamento em outro lugar, e uma nova forma de conexão com a terra de origem, haja vista o processo de transnacionalização da experiência migrante. Conforme menciona Velasco (2009, p. 33, tradução livre),"o estabelecimento de redes transnacionais incidem na forma que os migrantes têm de vincular-se ao país receptor sem deixar de manter laços com seus lugares de procedência" ${ }^{27}$.Não há, portanto, um rompimento, e sim uma relação de continuidade. Nesse sentido, Laguerre (1998, p. 08) destaca que a diáspora é um mecanismo de expansão da nação para além das fronteiras do Estado, o qual, por conseguinte, se modela seguindo seu próprio alargamento. Isto porque, "por sua própria estrutura, o Estado nacional está praticamente obrigado a dar preferência absoluta aos interesses de seus naturais"(VELASCO, 2009, p. 33, tradução livre) ${ }^{28}$, fazendo com que a existência diaspórica seja eixo agonístico daquela forma de configuração sócio-política. Em outras palavras, ela pode questionar formas de ser e pertencer mais democráticas, tensionando as fronteiras internas e externas dos Estados nacionais, haja vista serem estas essencialmente excludentes e discriminatórias - especialmente se as experiências diaspóricas sejam de sujeitos vindos de países periféricos, africanos, árabes, latinos.

\footnotetext{
${ }^{25}$ Do original, em espanhol: "vinculadas a los procesos de globalización y al progresivo reconocimiento de los derechos humanos, están surgiendo por la vía de hecho nuevos modelos de ciudadanía, con un componente territorial y nacional mucho menos marcado".

${ }^{26}$ Do original, em espanhol: "tiene la virtud de sacar a la luz las contradicciones internas del proyecto moderno de ciudadanía nacional".

${ }^{27}$ Do original, espanhol: "el establecimiento de redes transnacionales inciden en la forma que los migrantes tienen de vincularse al país receptor sin dejar de mantener lazos con sus lugares de procedencia”.

${ }^{28}$ Tradução livre, do original, espanhol: "por su propia estructura, el Estado nacional está prácticamente obligado a dar preferencia absoluta a los intereses de sus naturales”.
}

Revista de Direito Brasileira | Florianópolis, SC | v. 23 | n. 9 | p. 211-227 |Mai./Ago. 2019 
$\mathrm{O}$ autor destaca que a diaspóra ${ }^{29}$ não é somente a condição de residência em um país estrangeiro; pelo contrário, é também um estado de espírito, isto é

(...) as relações da diaspórapodem ser com uma terra natal ancestral ou com um terreno contestado mantido na memória individual ou coletiva devido à prévia ou suposta residência original do grupo em tempos memoriais. Diáspora é, portanto, tanto residência quanto um estado de espírito. (idem, p. 08, grifos nossos, tradução livre) $)^{30}$.

Além disso, o autor enfatiza a essência agonística, tensional, da experiência diaspórica, haja vista a natureza entre-lugares em que se posiciona a experiência migrante, no destino e na origem. Assim, conclui-se que

A diáspora encontra-se inserida no espaço de interstício do Estado-Nação receptor. A política do lugar é central para entender esse tipo de cidadania: a posição subjugada da diáspora vis-a-vis a cultura majoritária. O sujeito diaspórico é localizado vis-a-vis dois Estados: o Estado receptor, onde ele é considerado como um cidadão hifenizado, e a terra natal, onde ele é identificado como um nativo/estranho, não um estrangeiro, mas alguém cuja fidelidade está compartilhada com outro Estado-Nação..(ibidem, p. 10, grifos nossos, tradução livre) $)^{31}$.

O próprio Velasco (2009, p. 34, tradução livre, grifos nossos), falando de uma existência transnacional - pois ele não usou o termo diáspora, mas são conceitos que se assemelham ensina:

Por transnacionalismo migratório, entende-se como um conjunto de processos pelos quais determinados migrantes geram e sustentam relações e atividades sociais recorrentes que vinculam as sociedades de procedências com as de destino. A partir dessas relações e atividades, se constroem espaços sociais descontínuos e, como consequência, desterritorializados, espaços que cruzam fronteiras geográficas, culturais e políticas. (...) Constroem-se, assim, novos espaços transnacionais, que crescem em detrimento dos nacionais de base estritamente territorial ${ }^{32}$.

Frente a essa existência político-social móvel, duplamente situada, urge, portanto, uma nova concepção de cidadania, sendo insuficiente seu conceito tradicional, em que se submete ao

\footnotetext{
${ }^{29}$ Destaco ainda que tanto Laguerre quanto este trabalho destacam as experiências migrantes daquelas diásporas que se posicionam não como elites nos países de destino, mas que se inserem à semelhança dos "cidadãos comuns".

${ }^{30}$ Traduzido do original, em inglês: “(...) the relations of the diaspora may be to an ancestral homeland or to a contested terrain kept in one's memory or the collective memory because of the previous or supposed residence headquarters of the group in memorial times. Diaspora is thus both a residence and a state of mind".

${ }^{31}$ Traduzido do original, em inglês: "The diaspora finds itself inserted in the interstitial space of the receiving nation-state. The politics of location is central to understanding this form of citizenship: the subjugated position of the diaspora vis-a-vis the majority culture. The diasporic subject is located vis-à-vis two states: the host state where he is considered to be a hyphenated citizen, and the homeland where he is identified as an insider/outsider, not a foreigner, but someone whose allegiance is shared with another nation-state".

32 Traduzido do original, em espanhol: "Por transnacionalismo migratorio se entiende un conjunto de procesos por los cuales determinados migrantes generan y sostienen relaciones y actividades sociales recurrentes que vinculan las sociedades de procedencia con las de destino. A partir de esas relaciones y actividades se construyen espacios sociales discontinuos y, por ende, desterritorializados, espacios que cruzan fronteras geográficas, culturales y políticas. (...) Se han construído así nuevos espacios transnacionales, que crecen en detrimento de los nacionales de base estrictamente territorial".
}

Revista de Direito Brasileira | Florianópolis, SC | v. 23 | n. 9 | p.211-227 |Mai./Ago. 2019 
Estado-Nação. Ao situar a experiência migrante no campo da existência cidadã/diaspórica, se distancia de uma perspectiva assimilacionista, em que o movimento é unidirecional e implica o esquecimento forçado da memória histórica e ancestral da população imigrante. Falar de cidadania diaspórica, portanto, tem como consequência a transnacionalização da definição do conceito de cidadania, que perdura muitas vezes não só na primeira e segunda gerações de imigrantes, podendo se propagar indefinidamente. Assim,

A cidadania diaspórica inclui tanto a perspectiva nacional e transnacional, ligação e compromisso.Ela pressupõe algum nível de integração no país de residência e algum tipo de ligação com a terra natal. A intensidade dessas relações pode variar no tempo e de um indivíduo para outro, bem como de uma geração para a próxima.. (Laguerre, 1998, p. 13, grifos nossos, tradução livre) ${ }^{33}$.

Por fim, Laguerre conclui como as existências cidadãs diaspóricas são uma ameaça direta à existência do Estado-Nação como ele atualmente se constitui, uma vez que se torna impotente às experiências transnacionais de seus residentes, o que enfraquece progressivamente a sua soberania. O próprio Velasco (2009, p. 32, grifos nossos, tradução livre), já havia dito o mesmo, senão veja-se:

Ademais, a intensa marca deixada pelas migrações é perceptível no núcleo sensível do poder político e da convivência social, inclusive nos elementos articuladores dos Estados modernos: a noção de soberania nacional, o significado de cidadania ou das formas culturais da identidade coletiva e da lealdade política. Se a soberania nacional é corroída pelos processos de globalização, a impossibilidade de manter a integridade das fronteiras frente à pressão migratória intensifica esse processo ${ }^{34}$.

O local de expressão majoritária da cidadania, para essa população migrante, não mais se localiza dentro de fronteiras, mas implica um entre-lugar, e pode assim permanecer não somente na primeira geração, ainda que a tendência é que as práticas diaspóricas sejam redefinidas no campo das políticas raciais ou étnicas, a depender da população, pelas segundas ou posteriores gerações.

Ainda que Laguerre tenha construído sua tese tendo por base as práticas da comunidade de haitianos residentes nos EUA, é muito possível traçar paralelos com as existências imigrantes em outros locais. No Brasil, por exemplo, um imigrante haitiano se diz doente por ficar todas as noites ouvindo a rádio de seu país, ao passo que, durante o dia, ele vive numa cidade brasileira e convive com brasileiros ${ }^{35}$. No Rio de Janeiro, a comunidade congolesa realiza manifestação para demandar eleições na República Democrática do Congo e a saída do então presidente Kabila, ao mesmo tempo em que uma mulher da Gâmbia se insere nos movimentos negros de brasileiros da cidade. Em São Paulo e no Rio de Janeiro, grupos de imigrantes fundam a África do Coração.

\footnotetext{
${ }^{33}$ Traduzido do original, em inglês: "Diasporic citizenship includes both the national and transnational outlook, attachment, and commitment. It pre-supposes some level of integration in the country of residence and some kind of attachment with the homeland. The intensity of these relationships may vary over time from one individual to another and from one generation to the next".

${ }^{34}$ Traduzido do original, em espanhol: "Es más, la intensa impronta dejada por las migraciones es perceptible en el núcleo sensible del poder político y de la convivencial social, incluso en los elementos articuladores de los Estados modernos: la noción de soberanía nacional, el significado de la ciudadanía o las formas culturales de la identidad colectiva y de la lealtad política. Si la soberanía nacional se ha visto erosionada por los procesos de globalización, la imposibilidad de mantener la integridad de las fronteras ante la presión migratoria no ha hecho sino magnificar este proceso".

${ }^{35}$ Relato obtido de imigrante haitiano no eventorealizado na Faculdade Nacional de Direito da UFRJ pela ocasião do Dia Internacional dos Refugiados, em junho de 2017.
}

Revista de Direito Brasileira | Florianópolis, SC | v. 23 | n. 9 | p. 211-227 |Mai./Ago. 2019 
Grupos de estudantes africanos vão às escolas municipais do Rio Grande do Sul falar sobre África, africanidade e raça (CASTILHOS e MADEIRA, 2011). A existência cidadã é múltipla, é plural, é subjetiva, é transnacional, é diaspórica. Sejam regularesou não, esses grupos imigrantes ampliam e tensionam o sentido de cidadania, de democracia, e de Estado-Nação, contribuindo para a agonia necessária aos desígnios democráticos, tendo em vista que imprescindível para a democracia a constante e necessária mobilidade.

\section{CONCLUSÃO}

Chantal Mouffe, ao escrever sobre as potências agonísticas inerentes à existência e à manutenção das instituições democráticas não pretendia enfrentar as tensões representadas pelo paradigma nacional vs. estrangeiro. A autora objetivou tão-somente apresentar uma visão não utópica da política, e que mantivesse, em sua estrutura, o conflito entre os "indivíduos da democracia", nascido das relações humanas e suas disputas de poder, como fundamento para a propulsão de transformações na configuração de democracia e de cidadania. Essa democracia agonística é, para a autora, essencial para a sobrevivência das próprias instituições democráticas.

Balibar, por sua vez, demonstra como o conceito de cidadania é historicamente determinado, e desenvolve a tese da dialética constante e inerente aos conceitos de cidadania e democracia, numa clara versão da democracia agonística, de Mouffe. É neste sentido que o autor introduz o conceito de momentos insurrecionais, capazes (e necessários) de desestabilizar as estruturas de cidadania, a fim de reconstrui-la sob outros fundamentos - a dialética necessária, portanto, para a manutenção da democracia. Os movimentos sociais, nessa relação agonística, são responsáveis pela potência insurrecional de transformação dos modelos de cidadania.

É neste ponto que ler as migrações contemporâneas com a lente da cidadania implica, necessariamente, a percepção do contexto de sua crise no âmbito das sociedades ocidentais, bem como da potência insurrecional que representam os fluxos migratórios, naquilo que se refere às demandas subjetivas de cidadania que expressam enquanto movimentos sociais (MEZZADRA, 2005, p. 94). De fato, os fluxos migratórios "constituem (...) um fenômeno de efeitos estruturais que transforma profundamente a composição demográfica, o tecido social e as bases culturais de quase todas as sociedades"(VELASCO, 2009, p. 32, tradução livre) ${ }^{36}$, e, portanto,

Para abordar os novos ângulos da realidade migratória, são necessárias, sem dúvidas, outras noções políticas. A adoção de modelos pluralistas de pertencimento - como aquele que representa a cidadania múltipla constitui um reconhecimento formal do transnacionalismo migratório que tensiona a noção compacta de cidadania que costumam fazer os Estados nacionais de base territorial, a saber: como um conjunto unitário que englobaria, entre outros elementos, o lugar de residência, a identidade nacional, o desfrute de um sistema de direitos e a sujeição à legislação de um Estado. (idem, pp. 39-40, grifos nossos, tradução livre) ${ }^{37}$.

\footnotetext{
${ }^{36}$ Do original, em espanhol: "constituyen (...) un fenómeno de efectos estructurales que transforma profundamente la composición demográfica, el tejido social y el entramado cultural de casi todas las sociedades".

${ }^{37}$ Traduzido do original, em espanhol: "Para abordar los nuevos ángulos de la realidad migratoria se precisan, sin duda, otras nociones políticas. La adopción de modelos pluralistas de pertenencia - como el que representa la ciudadanía múltiple - constituye un reconocimiento formal del transnacionalismo migratorio que trastoca la noción compacta de ciudadanía que solían hacer suya los Estados nacionales de base territorial, a saber: como un conjunto unitario que englobaría entre otros elementos el lugar de residencia, la identidad nacional, el disfrute de un sistema de derechos y la sujeción a la legislación de un Estado".
}

Revista de Direito Brasileira | Florianópolis, SC | v. 23 | n. 9 | p.211-227 |Mai./Ago. 2019 
Defendemos, pois, na linha tanto de Mezzadra, Balibar, Velasco e de Laguerre, que os fluxos migratórios expressam seu caráter diaspórico e, portanto, ativam mudanças estruturais nas sociedades ocidentais no que tange à identificação de cidadania e nacionalidade. De fato,

Existem novas formas de ser e de pertencer que não podem ser abarcadas pelo Estado nacional e que transcendem à articulação tradicional da cidadania. Em definitivo, as formas de cidadania não somente estão sendo flexibilizadas e pluralizadas, mas também estão experimentando um intenso processo de ressignificação.. (VELASCO, 2009, p. 40, grifos nossos, tradução livre) ${ }^{38}$.

Necessário, pois, o nascimento de um conceito de cidadania diaspórica, que inclua em suas demandas, em especial, os direitos à residência e ao livre trânsito, numa clara alusão a Hannah Arendt ao demandar o "direito à cidade; o direito a residir com direitos", confirmando a tese pretendida do potencial democratizante, transformador, tensionador, enfim, agonístico dos fluxos migratórios, tendentes a repensar a estrutura estática e sedentária da atual cidadania formal. É possível dizer, enfim, que as migrações são capazes, portanto, de colocar a cidadania sob nova roupagem, qual seja, a diaspórica, uma urgência para as novas constituições de sociedade e de democracia.

\section{REFERÊNCIAS BIBLIOGRÁFICAS}

BALIBAR, Etiénne. Ciudadanía. Buenos Aires: Adriana Hidalgo Editora,2013.

. Strangers as Citizens: Further Reflections on the Aporias of Transnational Citizenship.

Disponível em: http://www.artcentersf.org/fall2016/parallaxdrift/wp-

content/uploads/2017/04/Strangers.pdf. Acesso aos 20 de dezembro de 2017.

. Cidadania, Nacionalidade, Soberania. Crítica Marxista, nº 3-4, Roma, julho, 1998.

BENHABIB, Seyla. AnotherCosmopolitanism.Londres: Editora Oxford, 2006.

CASTILHOS, Joelma S.; MADEIRA, Júlio César. África de Corpo e Alma: a Contribuição de Nativos Africanos para a Valorização da Cultura Negra em Sala de Aula. In: JOSEPH, Handerson; JOSEPH, Francine P. S. (Orgs.). Reflexões sobre a Questão Racial: Direito, Cidadania e Educação. Pelotas: Ed. Da UFPEL, 2011.

FLORES, Joaquín Herrera. Direitos Humanos, Interculturalidade e Racionalidade de Resistência. Sequência, v. 23, n. 44, Florianópolis, 2002.

FORNOS, J. L. Nacionalidade, colonialismo e imigração na literatura portuguesa. Literatura em Debate (URI) , v. 02, pp. 01-10, 2008.

GALLARDO, Helio. Derechos Humanos como Movimiento Social. Bogotá: Ediciones Desde Abajo, 2009.

\footnotetext{
${ }^{38}$ Do original, em espanhol: "Existen nuevas formas de ser y de pertenecer que no pueden ser abarcadas por el Estado nacional y que trascienden a la articulación tradicional de la ciudadanía. En definitiva, las formas de ciudadanía no sólo se están flexibilizando y pluralizando, sino que están experimentando un intenso proceso de resignificación".
}

Revista de Direito Brasileira | Florianópolis, SC | v. 23 | n. 9 | p. 211-227 |Mai./Ago. 2019 
HALL,Stuart. Da Diáspora: Identidades e Mediações Culturais.São Paulo: Editora Humanitas, 2003.

LAGUERRE, Michel. Diasporic Citizenship: Haitian Americans in Transnational America. Nova York: Palgrave Macmillan, 1998.

MEZZADRA, Sandro. Derecho de Fuga: migraciones, ciudadanía y globalización. Madri: Traficante de Sueños, 2005.

MOUFFE, Chantal. Por um Modelo Agonístico de Democracia. Revista de Sociologia Política, $\mathrm{n}^{\mathrm{o}}$ 25, Curitiba, nov., 2005, p. 11-23.

SAID, Edward. Reflexões sobre o exílio e outros ensaios. São Paulo: Companhia das Letras, 2003. P.46-60.

TAYLOR, Charles. El multiculturalismo y la política del reconocimiento. México: Fondo de Cultura Económica, 1993.

VELASCO, J. La noción republicana de ciudadanía y la diversidade cultural. Isegoría, v. 33, 2006, pp 191-206.

Transnacionalismo Migratorio y Ciudadanía en Mutación. Claves de Razón Práctica, n. 197, Madrid, pp. 32-41, 2009. 